\title{
FORAMINIFERAL RECORD OF CHANGES IN SUMMER MONSOON PRECIPI- TATION AT THE SOUTHEASTERN BRAZILIAN CONTINENTAL MARGIN SINCE THE LAST GLACIAL MAXIMUM
}

\author{
MARÍAALEJANDRA GÓMEZ PIVEL, FELIPE ANTONIO DE LIMA TOLEDO \\ \& KAREN BADARACO COSTA \\ Laboratório de Paleoceanografia do Atlântico Sul, Instituto Oceanográfico, USP, Praça do Oceanográfico, 191, 05508-900, \\ São Paulo, SP, Brazil.magomezpivel@usp.br,ftoledo@usp.br,karen.costa@.usp.br
}

\begin{abstract}
Changes in the oxygen isotopic composition of the planktonic foraminifer Globigerinoides ruber and in the foraminifera faunal composition in a core retrieved from the southeastern Brazilian continental margin were used to infer past changes in the hydrological balance and monsoon precipitation in the western South Atlantic since the Last Glacial Maximum (LGM). The results suggest a first-order orbital (precessional) control on the South American Monsoon precipitation. This agrees with previous studies based on continental proxies except for LGM estimates provided by pollen records. The causes for this disagreement are discussed.
\end{abstract}

Key words: foraminifera, precipitation, oxygen isotopes, South Atlantic Convergence Zone, South America Monsoon System, late Quaternary.

\begin{abstract}
RESUMO - A partir das mudanças na composição de isótopos de oxigênio do foraminífero planctônico Globigerinoides ruber e das mudanças na composição faunística ao longo de um testemunho coletado na margem continental sudeste do Brasil, foram inferidas mudanças no balanço hidrológico e na precipitação de monção no Atlântico Sul ocidental, desde o Último Máximo Glacial. Os resultados sugerem um controle de primeira ordem orbital sobre a precipitação de Monção da América do Sul, relacionado ao ciclo de precessão. Tal resultado está de acordo com estudos prévios baseados em proxies continentais, exceto com as estimativas para o Último Máximo Glacial fundamentadas em registros de pólen. No trabalho são discutidas as causas para esta divergência de resultados.
\end{abstract}

Palavras-chave: foraminíferos, precipitação, isótopos de oxigênio, Zona de Convergência do Atlântico Sul, Sistema de Monção da América do Sul, Quaternário tardio.

\section{INTRODUCTION}

Among all the atmospheric components, precipitation is probably the most critical one with the largest social and economic impacts (Carvalho et al., 2002). Both excess (floods) and insufficient (droughts) rainfall affect food (agriculture), freshwater and energy supplies. The last is particularly important in countries with a strong dependence on hydroelectrical energy, such as Brazil.

Most of the precipitation in southeastern Brazil is related to the South American Monsoon System (Zhou \& Lau, 1998). The present day variability in precipitation has been the subject of numerous recent studies (e.g. Robertson \& Mechoso, 2000; Zhou \& Lau, 2001; Paegle \& Mo, 2002; Carvalho et al., 2004; Kayano \& Andreoli, 2007). However, fewer studies have investigated the paleo record of precipitation variability on longer timescales in this region. How severe were the changes in precipitation in southeastern Brazil during the late Pleistocene and Holocene? Previous research has concentrated on continental areas with studies based on speleothems (e.g. Cruz et al., 2005a,b, 2006) and pollen records (e.g. Behling, 2002; Behling et al., 2002, 2007). Studies based on lake levels, diatom sequences, pollen, and charcoal at the Altiplano (e.g. Baker et al., 2001a,b; Paduano et al., 2003; Tapia et al., 2003) also provide an insight into the broader scale rainfall regime in South America. In order to provide a more complete view of monsoon precipitation, this study focused on the ocean sediments from the southeastern Brazilian continental margin.

Abundant marine evidence of past changes in precipitation is related to the supply of terrigenous sediments; however, in the study area, the Serra do Mar coastal mountain range prevents a significant supply of sediments to the continental margin. Most changes in the supply of terrigenous sediments in this area are related to sea-level changes that exposed the continental shelf during the glacial low sea-level stand favoring an increased supply from land. Pollen analyses in marine cores are also used to infer past hydrological changes. However, since onshore winds are dominant in this area, marine pollen records are also dependent on the fluvial input (Behling et al., 2002). 
In this study we used the estimates of Toledo et al. (2007) for the oxygen isotopic composition of seawater for the past $22 \mathrm{ka}$ from core SAN-76, retrieved from the southeastern Brazilian continental margin. Changes in the oxygen isotopic composition of seawater depend on both atmospheric fluxes and ocean circulation, but since atmospheric fluxes seem to be the primary controlling factors (Juillet-Leclerc et al., 1997), we used them to infer past changes in the hydrological balance. Furthermore, given that in the Atlantic Ocean the precipitation-evaporation balance closely reflects the rainfall distribution because of the much smaller variation of evaporation compared to precipitation (Tomckzak \& Godfrey, 2003), we assumed that most of the isotopic changes are linked to precipitation variations. Our data are compared with several other marine and continental paleorecords.

The time period investigated in this study involves a wide range of climatic conditions from the Last Glacial Maximum (LGM) to the present interglacial. The location chosen for our study is strategic since the analyzed core is located below the South Atlantic Convergence Zone (SACZ), and thus, the site is under the influence of monsoon precipitation.

\section{PRESENT SETTING}

The surface hydrography of the area is dominated by the Brazil Current, which moves southward along the shelf break, transporting warm and high salinity tropical water to the area. The sea surface temperature (SST) averages $24^{\circ} \mathrm{C}$, with seasonal variations of $4^{\circ} \mathrm{C}$. Annual mean sea surface salinity (SSS) is 36.5 (Levitus \& Boyer, 1994).

Precipitation in southeastern Brazil shows a clear seasonal pattern with most of the precipitation occurring during the warm season (from late September to April) associated with the South America Summer Monsoon (SASM). In winter, precipitation is of extratropical nature and associated with an enhanced frequency of migratory cyclones along the subtropical Atlantic coast (Gan \& Rao, 1991). Figure 1 shows the contrasting precipitation patterns between summer (monsoonal) and winter rainfall.

The major features of the SASM are schematically represented in Figure 2. Like all monsoon systems, the SASM is forced by the seasonally evolving land-sea thermal contrast. The upper-level circulation includes a large anticyclonic circulation centered near $15^{\circ} \mathrm{S} / 65^{\circ} \mathrm{W}$ and an upper-level trough near the coast of northeast Brazil (the "Nordeste Trough") (Vera et al., 2006). At low levels, a pronounced pressure low in the Gran Chaco area starting in early spring in response to rapid surface heating results in a well-developed low-level cyclone (the "Chaco low") during summer. The resulting pressure gradient between the south Atlantic subtropical high and the "Chaco low" favors northeasterly flow and related moisture fluxes from the Atlantic onto the continent (Paegle et al., 2002). Moisture transport intensifies locally along the eastern scarp of the Andes, where the South American Low-Level Jet develops with strongest winds over Bolivia. Since moisture flux over the continent is regulated by easterly trade winds resulting from the equato- rial branches of the North and South Atlantic subtropical highs, variations in location and intensity of these and concomitant SST variability influence the South American climate (Paegle \& Mo, 2002).

Today, the mature phase of the SASM occurs from late November through late February, when the main convective activity is centered over central Brazil and linked with a band of cloudiness and precipitation extending from southern Amazonia toward southeastern Brazil and the surrounding Atlantic Ocean. This convective precipitation band is the South Atlantic Convergence Zone (SACZ) (Kodama, 1992; Carvalho et al., 2002, 2004; Vera et al., 2006). The SACZ modulates the intensity and location of summer rain, exhibiting substantial changes in its strength and geographical extension on multiple timescales (Paegle \& Mo, 2002; Carvalho et al., 2004). The position and strength of the SACZ is largely influenced by the low-level wind regime which advects warm, moist air from the northwest and cool dry air from the southeast (Lenters \& Cook, 1999). The decay phase of the monsoon begins as convection shifts gradually northward toward the equator accompanying the decrease in solar heating over subtropical South America.

Compared to the well-known East Asian Summer Monsoon, the SASM is weaker and has a shorter life span. The reason is shorter and lower-altitude of the Altiplano Plateau (compared to its counterpart Tibetan Plateau) and its lowerlatitude location which causes the reduction of the efficiency of vorticity generated by horizontal divergence (Zhou \& Lau, 1998). However, the SASM accounts for over $80 \%$ of the annual mean precipitation at the center of the SACZ activity at about $23^{\circ} \mathrm{S}$, over Rio de Janeiro city (Cruz et al., 2006).

\section{MATERIAL AND METHODS}

Piston core SAN-76 was retrieved at the western South Atlantic Ocean at $24^{\circ} 26^{\prime} \mathrm{S}$ and $42^{\circ} 17^{\prime} \mathrm{W}$ at a water depth of $1,682 \mathrm{~m}$ (Figure 1). Twenty-three samples were analyzed. The age model and estimates of past changes in the isotopic composition of seawater were obtained from Toledo et al. (2007). Briefly, Toledo et al. (2007) used changes in the oxygen isotopic composition of the planktonic foraminifer Globigerinoides ruber to infer past changes in the oxygen isotopic composition of seawater after removing the temperature effect using the paleotemperature equation of Kim \& O'Neil (1997) and Wang et al.'s (1995) calibration between isotopic and real temperature for G. ruber in the low-latitude Atlantic. Subsequently, the global ice-volume effect was subtracted from the signal using estimates from Labeyrie et al. (1987). Paleo sea surface temperature (SST) estimates were based on the application of the SIMMAXMAT method on foraminiferal census counts (Pflaumann $e t$ al., 1996) performed on samples of at least 300 specimens of the $>150 \mathrm{~mm}$ fraction. The final error associated with the isotopic composition of seawater estimates is around $0.4 \%$.

Toledo et al.'s (2007) chronology was based on the correlation of the isotopic record of benthic foraminifera with the SPECMAP chronology of Martinson et al. (1987) and in 
four Accelerator Mass Spectrometer radiocarbon datings on samples of the monospecific planktonic foraminifer Globigerinoides ruber ( $>250 \mathrm{~mm}$ size). The ${ }^{14} \mathrm{C}$-AMS datings were performed at the NOSAMS-WHOI laboratory facility, and all the ${ }^{14} \mathrm{C}$ ages were corrected for a reservoir effect of 400 years (Bard, 1988) and transformed into calendar years (Table 1).

All isotope analyses were performed at the Woods Hole Oceanographic Institution (WHOI) laboratory facilities, using a Finnigan MAT252 with the automated Kiel device. The standard deviation of the isotope values of the National Bureau of Standards (NBS) carbonate standard NBS-19 was $0.08 \%$. NBS-19 isotope values were used to calibrate to Pee Dee Belemnite $\left(\delta^{18} \mathrm{O}=-2.2\right.$ Vienna Pee Dee Belemnite, VPDB). Data on the oxygen isotopic composition of planktonic foraminifera are based on the analysis of ten specimens of Globigerinoides ruber (white) larger than $212 \mathrm{~mm}$ in size in order to avoid size-dependent effects on the oxygen isotopes values.

\section{RESULTS AND DISCUSSION}

As discussed by Toledo et al. (2007), the oxygen isotopic record of planktonic foraminifera of core SAN-76 suggests that during the late Pleistocene and Holocene, the western tropical South Atlantic experienced significant hydrographic changes. Figure 3 presents the estimates of paleotemperature

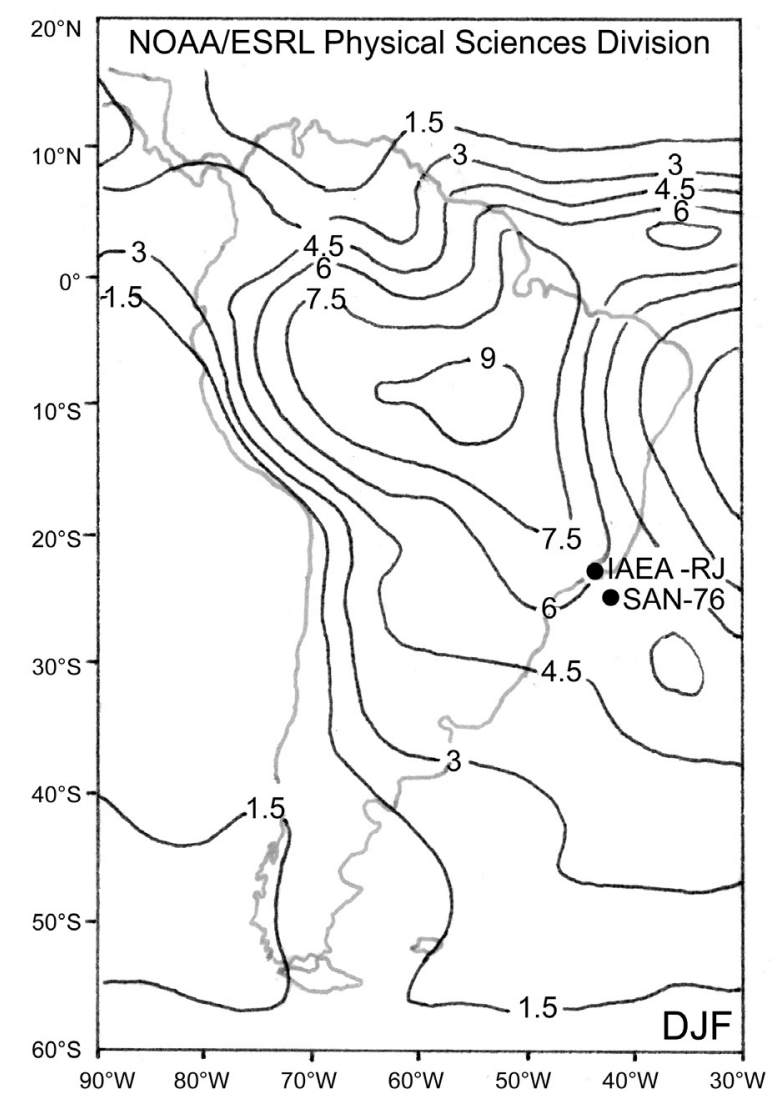

and paleo-oxygen isotopic composition of seawater for the past $22 \mathrm{ka}$ (Toledo et al., 2007). Consistent with recent studies (e.g. Otto-Bliesner et al., 2008; MARGO Project Members, 2009), the estimates suggest that tropical cooling during the LGM was relatively modest (around $2^{\circ} \mathrm{C}$ ). This change is larger than the one previously suggested by CLIMAP $(1976,1981)$ but significantly smaller than other estimates based on continental data such as noble gases (Stute et al., 1995) and palynological records (e.g. Behling \& Lichte, 1997). As expected, the highest temperatures occurred in the Holocene, between 4 and $6 \mathrm{ka}$ BP and in present conditions, and the lowest temperatures occurred at the LGM, around $21 \mathrm{ka} \mathrm{BP}$.

Since temperature seems to have been relatively stable, the hydrographic changes recorded by the oxygen isotopic composition of planktonic foraminifera, must have been related to salinity changes which are primarily the result of

Table 1. Radiocarbon age control points obtained by accelerator mass spectrometry (AMS) (according to Toledo et al., 2007).

\begin{tabular}{c|c|c}
\hline Depth in core $(\mathrm{cm})$ & ${ }^{14} \mathrm{C}$ age (years) & Calendar age (y ears) \\
\hline 13 & 3,010 & 2,756 \\
148 & 13,450 & 15,516 \\
320 & 19,300 & 22,374 \\
416 & 29,400 & 33,583 \\
\hline
\end{tabular}

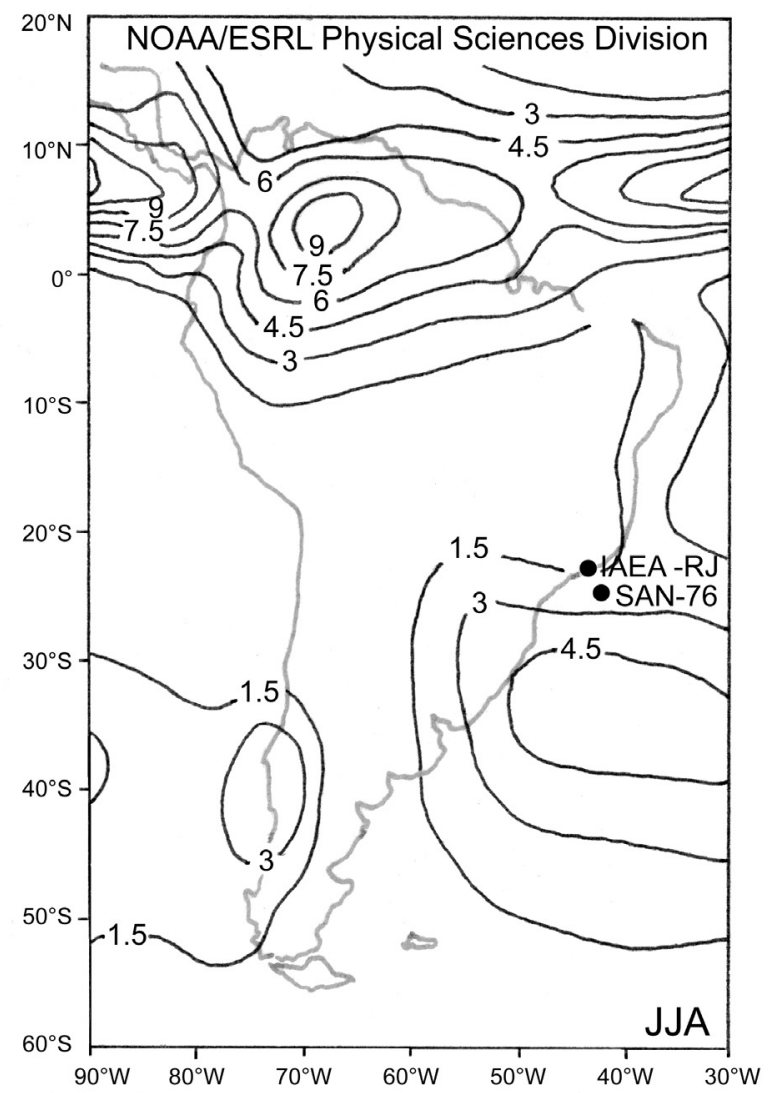

Figure 1. Locations of the studied core SAN-76 and IAEA station at Rio de Janeiro (see "comparison with other proxy data") relative to the long-term mean (1979-2000) precipitation from the Climate Prediction Center Merged Analysis (CMAP) in mm/day for austral summer (DJF) (left) and winter (JJA) (right) (modified from Xie \& Arkin, 1997). 
the local hydrological balance. Secondarily, the large-scale circulation could be responsible for some of the observed changes in the oxygen isotopic composition of seawater. The influence of ocean circulation would be through changes in the strength of the Meridional Overturning Circulation (MOC). For instance, during the deglacial meltwater events, a weakening of the thermohaline overturn would cause a reduction in the northward advection of warm, saline surface waters and, thus, a heat and salt accumulation in the upper layers of the tropical ocean (Manabe \& Stouffer, 1997; Rühlemann et al., 1999; Dahl et al., 2005). However, the maximum warming anomaly would have probably occurred at intermediate water depths rather than in the most superficial waters because of the air-sea process which would dampen the SST response (Dahl et al., 2005). This means that an increase in SSS related to the ocean circulation would not necessarily be accompanied by a SST increase.

The gradual decrease in the oxygen isotopic composition of seawater during the Holocene (Figure 3 ) is consistent with the intensification of the thermohaline circulation which would reestablish the heat and salt export to the northern Atlantic causing a freshening of the tropical Atlantic. However, since we believe that the hydrological balance is the most important factor determining the oxygen isotopic composition of seawater, we hypothesize that besides the role of the MOC intensification, the gradual freshening of the tropical Atlantic during the Holocene could also be related to increased precipitation.

Considering that most of the precipitation in the study area is related to the SASM and the influence of changes in summer season insolation on the strength of monsoon climates has long been recognized and documented by climate models (e.g. Kutzbach \& Otto-Bliesner, 1982; Prell \& Kutzbach, 1987; Valdes \& Glover, 1999; Liu et al., 2003b), we compared the oxygen isotopic composition of seawater (after excluding the global ice volume effect) with summer insolation (Figure 4). The general agreement between estimates of the oxygen isotopic composition of seawater and summer season insolation supports the idea of the oxygen isotopic record of seawater reflecting solar induced changes in precipitation related to the intensity of the SASM. Higher (lower) insolation translates into an enhanced (decreased) temperature (and thus, pressure) contrast between land and ocean, and a stronger (weaker) monsoon leads to increased (decreased) precipitation.

Based on Figure 4, we deduce that maximum precipitation occurred around the LGM and during the late Holocene and that minimum precipitation occurred around $12 \mathrm{ka} \mathrm{BP}$ when

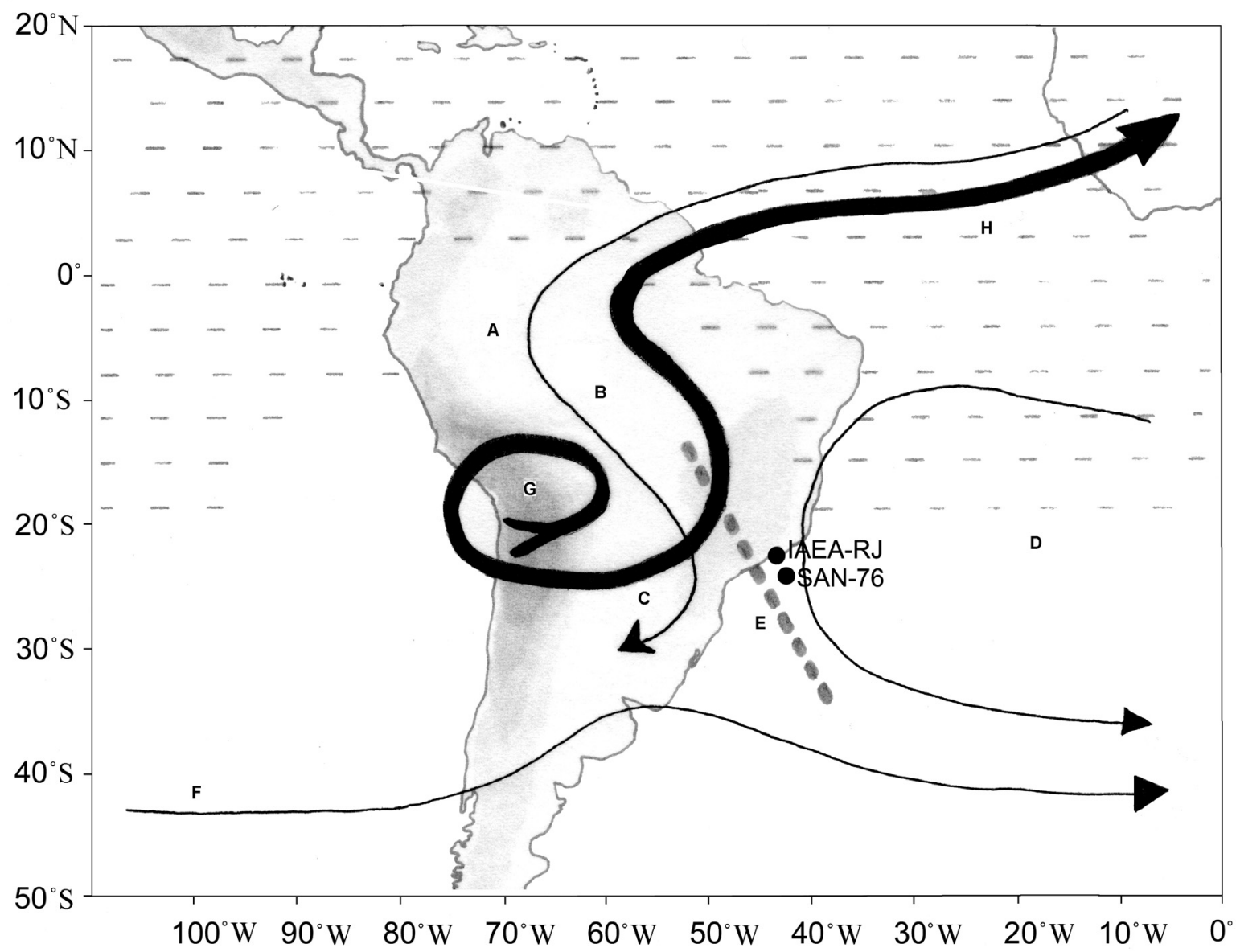

Figure 2. America summer monsoon features represented in a schematic illustration modified from Zhou \& Lau (1998). The locations of core SAN-76 and IAEA station at Rio de Janeiro are also identified. A, low-level cross-equatorial flow; B, northwesterlies vs southeasterlies; C, Gran Chaco low; D, subtropical high; E, South Atlantic Convergence Zone (SACZ); F, midlatitude westerlies; G, Bolivian high; H, upperlevel return flow. 
the Earth was farther from the sun in December and the continent did not warm up as much as today during the austral summer. The reduced land-sea thermal contrast around $12 \mathrm{ka}$ BP would have caused a weakening of the SASM and thus, decreased precipitation. As expected, this pattern is opposite to the one documented for the North African monsoon where the early Holocene was characterized as a humid phase known as the African Humid Period (Roberts, 1998). This humid period was caused by the increased summer insolation in the Northern Hemisphere which brought significant rainfall to today's Sahara desert supporting a landscape of grasslands, lakes and wetlands (COHMAP Members, 1988). Similarly, wetter-than-today conditions during the Early Holocene in southwestern North America (e.g. Bird \& Kirby, 2006; Kirby et al., 2007) and China (e.g. An et al., 2000) are related to the enhanced North American and Asian monsoons.

Despite the general agreement between the stronger/ weaker monsoon systems from opposite hemispheres, the correlation is not perfect because, as demonstrated by both paleoclimate proxy data and models, the response of monsoon systems to insolation is not linear and because it differs substantially between regions due to feedbacks related to vegetation cover, surface ocean temperature, and moisture
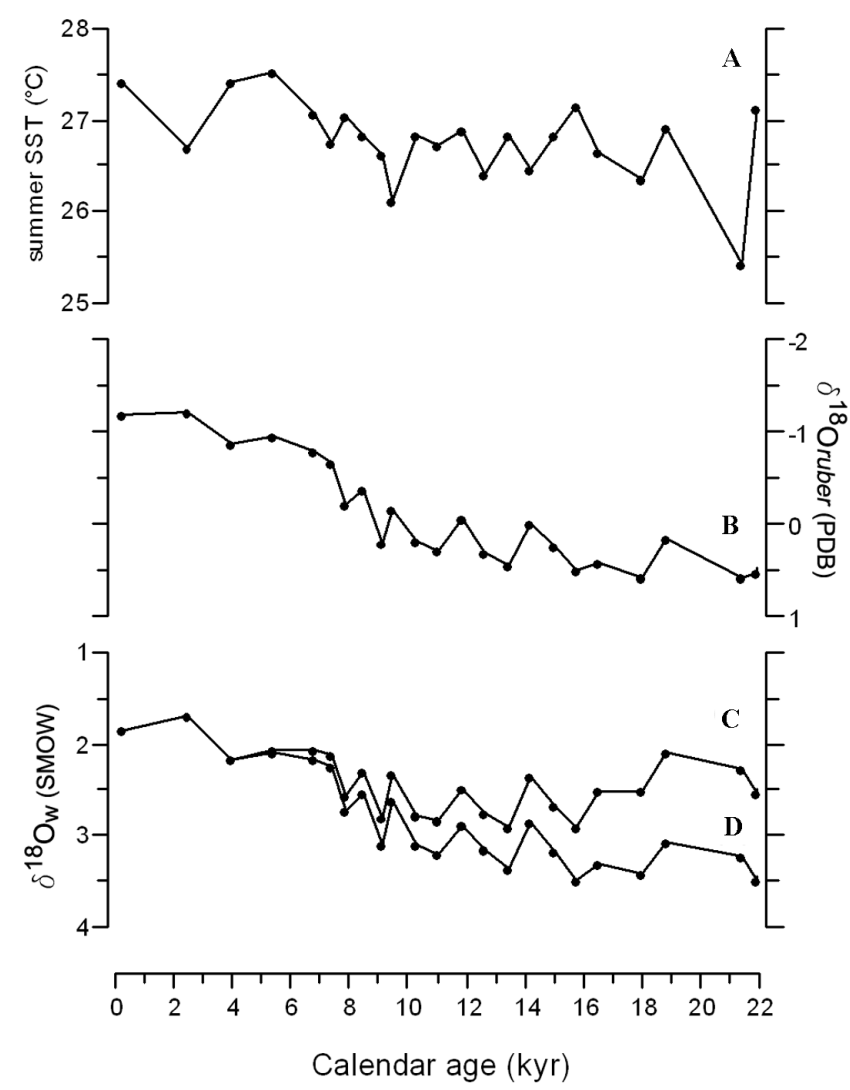

Figure 3. Estimates. A, summer SST (in ${ }^{\circ} \mathrm{C}$ ) based on the application of the SIMMAX-MAT method on foraminiferal census counts; B, oxygen isotopic composition of the planktonic foraminifer Globigerinoides ruber (in PDB); C, oxygen isotopic composition of surface seawater (SMOW) after excluding the ice volume effect; D, oxygen isotopic composition of surface seawater (SMOW) including the ice volume effect (according to Toledo et al., 2007). availability (e.g. Kutzbach \& Guetter, 1986; Kutzbach et al., 1996; Kutzbach \& Liu, 1997; Claussen et al., 1999; de Menocal et al., 2000; Carrington et al., 2001; Liu et al., 2004). These feedbacks may significantly amplify or dampen the initial insolation forcing. Although the understanding of those feedbacks is constantly being improved thanks to climate models which have evolved from low-resolution atmosphereonly models to complex coupled land-atmosphere models, many important questions remain open, especially for monsoons outside the North African-Asian region (Liu et al., 2003a).

As seen in Figure 4, late Holocene values of the isotopic composition of seawater were lower than LGM values. Although this difference is within the error of the method, it could be related to higher precipitation conditions in the late Holocene than during the LGM. This, in turn, could be the result of global-scale feedbacks related to glacial conditions, including the large changes in greenhouse gases, aerosols, ice sheets, sea level and vegetation, although according to modeling studies (Kutzbach \& Guetter,1986; Clement et al., 2004) the response to precessional forcing in the tropics is likely to be somewhat independent of the glacial-interglacial variations, particularly in variables relating to the hydrological cycle. Nevertheless, even a small cooling of tropical and subtropical oceans would be enough to reduce the moisture content of the lower atmosphere, leading to reduced ascending motion and decreased precipitation. Also, the reduced land-sea temperature contrast during the LGM related to cooler conditions over the continent (e.g. Stute et al., 1995; Behling \& Lichte, 1997) compared to the ocean (e.g. Niebler et al., 2003; Toledo et al., 2007) could have been responsible for a weakening of the SASM.

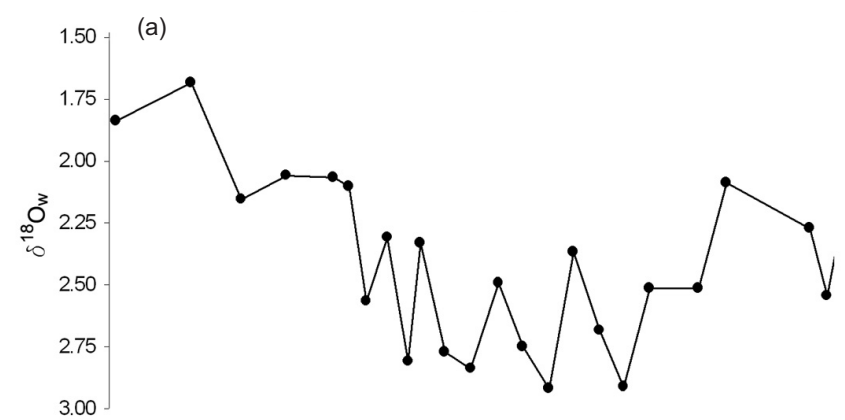

(b)

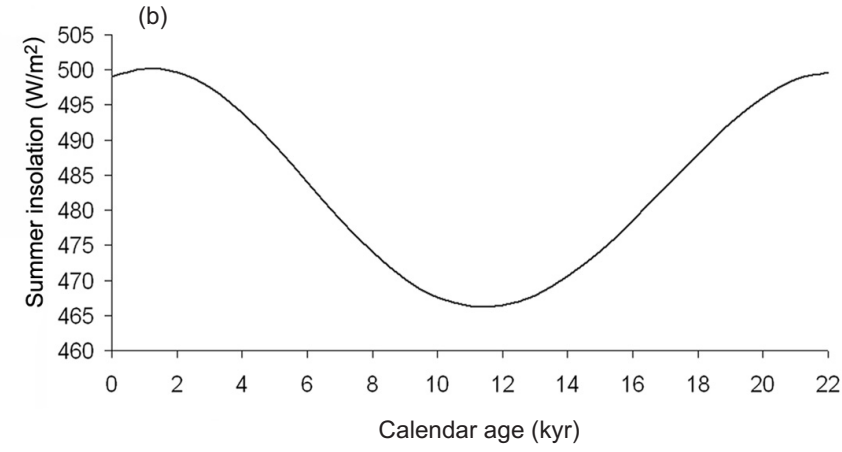

Figure 4. Comparison between (a) the oxygen isotopic composition of seawater after excluding the global ice volume effect (vs. SMOW) and (b) austral summer solstice insolation at $24^{\circ} \mathrm{S}\left(\mathrm{W} / \mathrm{m}^{2}\right)$ (adopted from Berger \& Loutre, 1991; Berger, 1992). 
The extent to which climate variability is driven externally by insolation changes or internally by feedbacks among climate system components is hard to determine. Although the role of oceanic feedback on monsoon intensity is still poorly understood, it is recognized that even small SST anomalies may have a significant impact on regional monsoons, because they occur in large areas in the tropics that may generate substantial forcing to atmospheric circulation (Liu et al., 2003b).

\section{Comparison with other proxy data}

A drier early Holocene and wetter late Holocene have also been suggested by palynological records from SE Brazil (Behling, 2002; Behling et al., 2007). However, unlike our record, palynological studies suggest a maximum expansion of grassland vegetation and a reduction of Atlantic rainforest and semideciduous forest during the LGM which, according to the authors, would be the response to cold and dry conditions (Behling et al., 2002). On the one hand, the disagreement between our record and the palynological data for the LGM could be partially explained by the fact that the oxygen isotopic record was of the species Globigerinoides ruber. Since the highest concentrations of G. ruber are associated with the summer months (Tolderlund \& Bé, 1971), our oxygen isotopic composition of seawater record is very likely representative of summer conditions, while the palynological record would represent an integration of all seasons. This is relevant because of the susceptibility of vegetation to changes in the seasonality of precipitation. For instance, in a study in the northwestern Brazilian Amazon forest, Bush et al. (2004) showed that forests in that area can be relatively resistant to changes in wet season rains but more susceptible to changes in dry season precipitation. Thus, we cannot expect a perfect correlation between pollen and $G$. ruber records.

On the other hand, another likely explanation for the apparent disagreement is the problem of the "no-analog" situation for the pollen data because of the changes in atmospheric $\mathrm{CO}_{2}$ concentration (Crowley, 2000). During the LGM, $\mathrm{CO}_{2}$ concentration was considerably lower than in the late Holocene ( $c a$. 180-200 ppm atmospheric $\mathrm{CO}_{2}$ versus preindustrial values of 280 ppm; Monnin et al., 2001). Since $\mathrm{C}_{4}$ plants (some grasses) possess a mechanism of concentrating $\mathrm{CO}_{2}$, they are favored by low $\mathrm{CO}_{2}$ concentrations (Ehleringer et al., 1997). For this reason, the decreased abundance of $\mathrm{C}_{3}$ (i.e. leafy) plants during the LGM cannot be exclusively attributed to climatic variables (i.e. precipitation and temperature) (Huang et al., 2001; Mayle et al., 2004). Instead, vegetational changes are a complex response to temperature, precipitation, seasonality, and $\mathrm{CO}_{2}$ concentration changes.

The cause behind the disagreement between our estimates based on the oxygen isotopic values of Globigerinoides ruber and the estimates based on pollen analyses for the LGM is most likely a combination of both of the above factors. Changes in atmospheric $\mathrm{CO}_{2}$ concentration prevent us from drawing direct conclusions about the precipitation regime based exclusively on pollen analyses, but there is also the drawback of the G. ruber record representing mostly summer conditions.

In addition to the palynological records from SE Brazil, we compared our results with those from studies on the hydrological changes at the South American Altiplano where precipitation is also dependent on the strength of the SASM. Although it is near the Pacific Ocean, the main moisture source for the northern Altiplano is the Amazon Basin to the north and east (Cross et al., 2001). Paleorecords of the Altiplano (e.g. Baker et al., 2001a,b; Paduano et al., 2003; Tapia et al., 2003) as well as modeling studies (e.g. Cross et al., 2001) also agree on the large-scale control of southern tropical moisture conditions by austral summer-insolation influence on the SASM. Peak summer insolation in the Southern Hemisphere during the LGM induced increased precipitation which resulted in a deep, fresh, overflowing (Baker et al., 2001a), and slightly larger than at present Lake Titicaca (Wirrmann \& Mourguiart, 1995). Farther south on the Bolivian Altiplano, a large, deep lake existed, where today it is the salt flat Salar de Uyuni (Baker et al., 2001b), suggesting that despite the similar insolation intensity, LGM conditions were wetter than in the late Holocene or, alternatively, that monsoon precipitation significantly extended southwards during the LGM. An extensive dry phase in the early to mid-Holocene coincident with decreased insolation caused a lake-level drop of approximately $85 \mathrm{~m}$ (Rowe et al., 2003). The peak of pollen concentration and of fire frequency at $c a .5 .5 \mathrm{ka} \mathrm{BP}$ coincides with the estimate of lowest lake level (Paduano et al., 2003; Baker et al., 2001b). Finally, the shift toward a strengthened summer monsoon occurred between 5 and $6 \mathrm{ka} \mathrm{BP}$ (Rowe et al., 2003). After $4 \mathrm{ka}$ BP, precipitation filled the Titicaca basin and overflow conditions were re-established (Tapia et al., 2003).

The oxygen isotope record from SE Brazil speleothems also agrees with a dominant control of summer insolation on long-term seasonal changes over subtropical Brazil (Cruz et al., 2005a, 2006). Today, the seasonal variations in the isotopic composition of rainfall over subtropical regions is related to seasonal changes in the relative contribution of precipitation from different sources, as shown by Cruz et al. (2005b) (Figure 1). The incursion of extratropical air masses during winter to early spring brings relatively enriched moistures from the nearby Atlantic. On the other hand, during the summer monsoon, higher percentages of isotopically-depleted, continental moisture originating over the Amazon Basin are transported southeastward by a low level jet. Thus, an increase in monsoon precipitation is represented by decreased speleothem $\delta^{18} \mathrm{O}$ values. The oxygen isotopic composition of monsoon precipitation is further decreased because of the "amount effect," i.e., the correlation of the depletion of heavy isotopes with the amount of rain (Dansgaard, 1964; Gat et al., 2001; Vuille \& Werner, 2005). Data from IAEA station near core SAN-76, at Rio de Janeiro $\left(\sim 23^{\circ} \mathrm{S}\right)$, clearly show the significance of the amount effect at this location (Figure 5) (Cruz et al., 2005b).

Although the oxygen isotopic composition of seawater is mostly dependent on the hydrological balance (E-P 

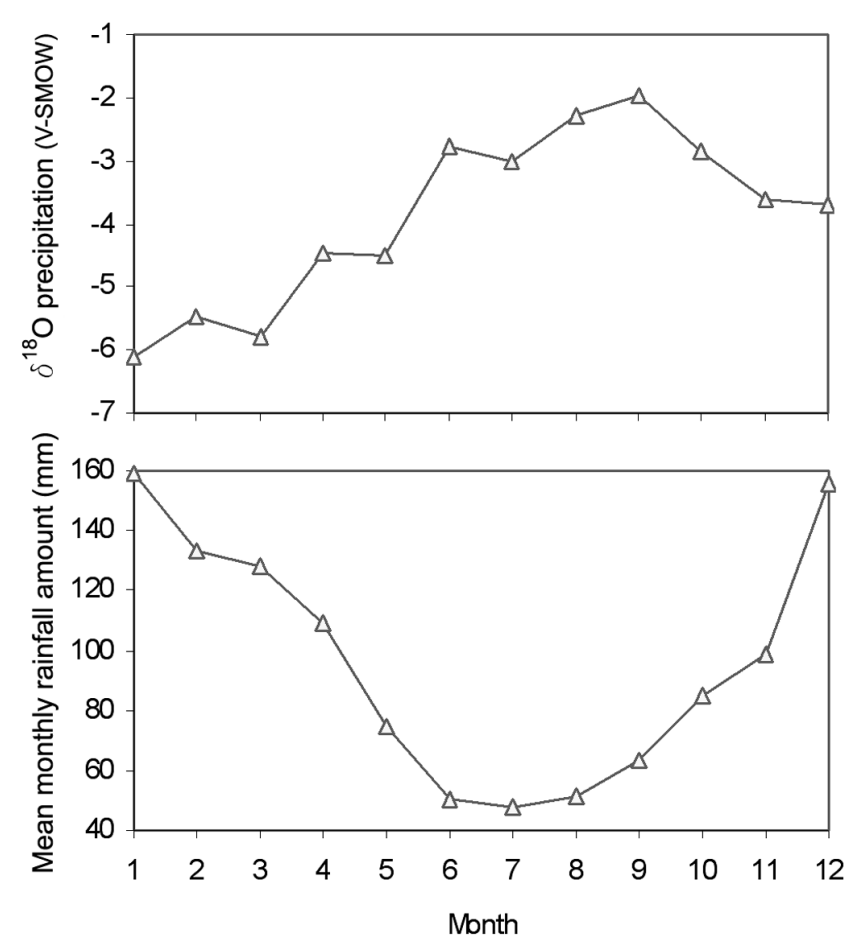

Figure 5. Oxygen isotopic composition of precipitation and mean monthly amount of precipitation in Rio de Janeiro $\left(22.9^{\circ} \mathrm{S} / 43.17^{\circ} \mathrm{W}\right)$ (IAEA/WMO, 2004).

budget), which explains its high correlation with sea surface salinity, it may also be influenced by changes in the isotopic composition of precipitation. Data from the IAEA station at Rio de Janeiro show that the oxygen isotopic composition of precipitation in the area of core SAN-76 varies seasonally from -2 to $-6 \%$ (SMOW) (Figure 5). As mentioned, the lowest values are related to the precipitation from the SACZ. This rainfall exhibits relatively low values of $\delta^{18} \mathrm{O}$ because it incorporates a higher fraction of depleted moisture that is transported from the distant Amazon Basin to the Brazilian subtropics by the South American low-level jet (Cruz et al., $2005 \mathrm{~b}, 2006)$. Also, the availability of depleted moisture from distal sources in this region tends to be proportional to the degree of rainout of ${ }^{18} \mathrm{O}$ over the Amazon Basin, which is enhanced during more intense phases of the summer monsoon (Vuille \& Werner, 2005; Cruz, 2006). This means that a more intense summer monsoon leads to increased precipitation and more negative $\delta^{18} \mathrm{O}$ values. Thus, if the oxygen isotopic composition of precipitation effectively influences the oxygen isotopic composition of seawater in this area, the effect would be in the same direction of the hydrological balance, and it would not interfere with our interpretation. Instead, it would simply amplify the seawater $\delta^{18} \mathrm{O}$ changes (increased precipitation-lower rainfall $\delta^{18} \mathrm{O}$ values-lower seawater $\left.\delta^{18} \mathrm{O}\right)$.

\section{CONCLUSIONS}

This study reinforces the significance of foraminifera as climate proxies. Estimates of the oxygen isotopic composition of seawater in the western tropical Atlantic were obtained based on the isotopic composition of Globigerinoides ruber and changes in the faunal composition of planktonic foraminifera. These estimates showed significant changes since the LGM. Suborbital-scale changes were interpreted as the result of precipitation changes related to the intensity of the SASM which is governed by precessional forcing. In agreement with other continental data, our record suggests an intensified monsoon during the LGM and mainly during the late Holocene coinciding with maximum summer insolation and a weakened monsoon in the early Holocene. As expected, these records are in opposition to those from the northern hemisphere monsoons.

\section{ACKNOWLEDGMENTS}

This work was financially supported by FAPESP (Fundação de Amparo à Pesquisa do Estado de São Paulo, process 04/02819-8) and by a grant from the CNPq (Conselho Nacional de Desenvolvimento Científico e Tecnológico, process 141577/2005-3). We thank Petrobras for providing the samples. CMAP precipitation data was provided by the NOAA/OAR/ ESRL PSD, Boulder, CO, USA, from their web site at http:// www.cdc.noaa.gov/. We thank L. David Roper for his Windows program to compute orbital parameters and insolation according to the solution of Berger (1978) (http:// arts.bev.net/roperldavid/InsolationCodes.htm). This is Laboratório de Paleoceanografia do Atlântico Sul (LaPAS), IOUSP, contribution number 10 .

\section{REFERENCES}

An, Z.; Porter, S.C.; Kutzbach, J.E.; Xihao, W.; Suming, W.; Xiaodong, L.; Xiaoqiang, L. and Weijian, Z. 2000. Asynchronous Holocene optimum of the East Asian monsoon. Quaternary Science Reviews, 19:743-762.

Baker, P.A.; Seltzer, G.O.; Fritz, S.C.; Dunbar, R.B.; Grove, M.J.; Tapia, P.M.; Cross, S.L.; Rowe, H.D. \& Broda, J.P. 2001a. The history of South American tropical precipitation for the past 25,000 years. Science, 291:640-643.

Baker, P.A.; Rigsby. C.A.; Seltzer, G.O.; Fritz, S.C.; Lowenstein, T.K.; Bacher, N.P. \& Veliz, C. 2001b. Tropical climate changes at millennial and orbital timescales on the Bolivian Altiplano. Nature, 409:698-701.

Bard, E. 1988. Correction of accelerator mass spectrometry ${ }^{14} \mathrm{C}$ ages measured in planktonic foraminifera: Paleoceanographic implications. Paleoceanography, 3:635-645.

Behling, H. 2002, South and southeast Brazilian grasslands during late Quaternary times: a synthesis. Palaeogeography, Palaeoclimatology, Palaeocology, 177:19-27.

Behling, H. \& Lichte, M. 1997. Evidence of dry and cold climatic conditions at glacial times in tropical southeastern Brazil. Quaternary Research, 48:348-358.

Behling, H.; Arz, H.W.; Pätzold, J. \& Wefer, G. 2002. Late Quaternary vegetational and climate dynamics in southeastern Brazil, inferences from marine cores GeoB 3229-2 and GeoB 3202-1. Palaeogeography, Palaeoclimatology, Palaeocology, 179:227-243.

Behling, H.; Dupont, L.; Safford, H.D. \& Wefer, G. 2007. Late Quaternary vegetation and climate dynamics in the Serra da 
Bocaina, southeastern Brazil. Quaternary International, 161:2231.

Berger, A. 1992. Orbital variations and insolation database. IGBP PAGES/World Data Center-A for Paleoclimatology Data Contribution Series \# 92-007. NOAA/NGDC Paleoclimatology Program, Boulder CO, USA.

Berger A. \& Loutre M.F. 1991. Insolation values for the climate of the last 10 million years. Quaternary Sciences Reviews, 10:297317.

Bird, B.W. \& Kirby, M.E. 2006. An alpine lacustrine record of early Holocene North American Monsoon dynamics from Dry Lake, southern California (USA). Journal of Paleolimnology, 35:179-192.

Bush, M.B.; De Oliveira, P.E.; Colinvaux, P.A.; Miller, M.C. \& Moreno, J.E. 2004. Amazonian paleoecological histories: one Hill, three watersheds. Palaeogeography, Palaeoclimatology, Palaeocology, 214:359-393.

Carrington, D.P.; Gallimore, R.G. \& Kutzbach, J.E. 2001. Climate sensitivity to wetlands and wetland vegetation in mid-Holocene North Africa. Climate Dynamics, 17:151-157.

Carvalho, L.M.V.; Jones, C. \& Liebmann, B. 2002. Extreme precipitation events in southeastern South America and largescale convective patterns in the South Atlantic Convergence Zone. Journal of Climate, 15:2377-2394.

Carvalho, L.M.V.; Jones, C. \& Liebmann, B. 2004. The South Atlantic Convergence Zone: intensity, form, persistence, and relationships with intraseasonal to interannual activity and extreme rainfall. Journal of Climate, 17:88-108.

Claussen, M.; Kubatzki, C.; Brovkin, V.; Ganopolski, A.; Hoelzmann, P. \& Pachur, H.J. 1999. Simulation of an abrupt change in Saharan vegetation in the mid-Holocene. Geophysical Research Letters, 26:2037-2040.

Clement, A.C.; Hall, A. \& Broccoli, A.J. 2004. The importance of precessional signals in the tropical climate. Climate Dynamics, 22:327-341.

CLIMAP 1976. The surface of the Ice-Age Earth. Science, 191:1131-1137.

CLIMAP 1981. Seasonal reconstructions of the Earth's surface at the Last Glacial Maximum. Geological Society of America Map and Chart Series, MC-36:1-18.

COHMAP Members 1988. Climatic changes of the last 18,000 years: observations and model simulations. Science, 241:10431052.

Crowley, T.J. 2000. CLIMAP SSTs re-revisited. Climate Dynamics, 16:241-255.

Cross, S.L.; Baker, P.A.; Seltzer, G.O.; Fritz, S.C. \& Dunbar, R.B. 2001. Late Quaternary climate and hydrology of tropical South America inferred from an isotopic and chemical model of Lake Titicaca, Bolivia and Peru. Quaternary Research, 56:1-9.

Cruz, F.W.; Burns, S.J.; Karmann, I.; Sharp. W.D.; Vuille, M.; Cardoso, A.O.; Ferrari, J.A.; Silvas Dias, P.L. \& Viana Jr, O. 2005a. Insolation-driven changes in atmospheric circulation over the past 116,000 years in subtropical Brazil. Nature, 434:63-66.

Cruz, F.W.; Karmann, I.; Viana Jr, O.; Burns, S.J.; Ferrari, J.A.; Vuille, M.; Sial, A.N. \& Moreira, M.Z. 2005b. Stable isotope study of cave percolation waters in subtropical Brazil: implications for paleoclimate inferences from speleothems. Chemical Geology, 220:245-262.

Cruz, F.W.; Burns, S.J.; Karmann, I.; Sharp, W.D. \& Vuille, M.
2006. Reconstruction of regional atmospheric circulation features during the late Plesitocene in subtropical Brazil from oxygen isotope composition of speleothems. Earth and Planetary Science Letters, 248:494-506.

Dahl, K.A.; Broccoli, A.J. \& Stouffer, R.J. 2005. Assessing the role of North Atlantic freshwater forcing in millennial scale climate variability: a tropical Atlantic perspective. Climate Dynamics, 24:325-346.

Dansgaard, W. 1964. Stable isotopes in precipitation. Tellus, 16:436468.

de Menocal, P.; Ortiz, J.; Guilderson, T.; Adkins, J.; Sarnthein, M.; Baker, L. \& Yarusinsky, M. 2000. Abrupt onset and termination of the African Humid Period: rapid climate responses to gradual insolation forcing. Quaternary Science Reviews, 19:347-361.

Ehleringer, J.R.; Cerling, T.E. \& Helliker, B.R. 1997. C 4 photosynthesis, atmospheric $\mathrm{CO}_{2}$, and climate. Oecologia, 112:285-299.

Gan, M.A. \& Rao, V.B. 1991. Surface cyclogenesis over South America. Monthly Weather Review, 119:1293-1302.

Gat, J.R.; Mook, W.G. \& Meijer, H.A.J. 2001. Atmospheric water. Paris, UNESCO, IHP-V, 113 p. (Technical Documents in Hydrology 39-II).

Huang, Y.; Street-Perrott, F.A.; Metcalfe, S.E.; Brenner, M.; Moreland, M. \& Freeman, K.H. 2001. Climate change as the dominant control on glacial-interglacial variations in $\mathrm{C}_{3}$ and $\mathrm{C}_{4}$ plant abundance. Science, 293:1647-1651.

IAEA/WMO 2004. Global network of isotopes in precipitation. The GNIP Database. International Atomic Energy Agency, Vienna. Available at: http://isohis.iaea.org; accessed on 10/03/ 2009.

Juillet-Leclerc, A.; Jouzel, J.; Labeyrie, L. \& Joussaume, S. 1997. Modern and last glacial maximum sea surface $\delta^{18} \mathrm{O}$ derived from an Atmospheric General Circulation Model. Earth and Planetary Science Letters, 146:591-605.

Kayano, M.T. \& Andreoli, R.V. 2007. Relations of South American summer rainfall interannual variations with the Pacific Decadal Oscillation. International Journal of Climatology, 27:531-540.

Kim, S.-T. \& O'Neil, J.R. 1997. Equilibrium and nonequilibrium oxygen isotope effects in synthetic carbonates. Geochimica et Cosmochimica Acta, 61:3461-3475.

Kirby, M.E.; Lund, S.P.; Anderson, M.A. \& Bird, B.W. 2007. Insolation forcing of Holocene climate change in Southern California: a sediment study from Lake Elsinore, Journal of Paleolimnology, 38:395-417.

Kodama, Y.M. 1992. Large-Scale common features of Sub-Tropical Convergence Zones (the Baiu Frontal Zone, the SPCZ, and the SACZ) Part II : conditions of the circulations for generating the STCZs. Journal of the Meteorological Society of Japan, Series II, 71:581-610.

Kutzbach, J.E. \& Guetter, P.J. 1986. The influence of changing orbital parameters and surface boundary conditions on climate simulations for the past 18000 years. Journal of the Atmospheric Sciences, 43:1726-1759.

Kutzbach, J.E. \& Liu, Z. 1997. Response of the African Monsoon to orbital forcing and ocean feedbacks in the middle Holocene. Science, 278:440-443.

Kutzbach, J.E. \& Otto-Bliesner, B.L. 1982. The sensitivity of the African-Asian monsoonal climate to orbital parameter changes for 9000 years B.P. in a low-resolution general circulation model. Journal of the Atmospheric Sciences, 39:1177-1188. 
Kutzbach, J.; Bonan, G.; Foley, J. \& Harrison, S.P. 1996. Vegetation and soil feedbacks on the response of the African monsoon to orbital forcing in the early to middle Holocene. Nature, 384:623626.

Labeyrie, L.D.; Duplessy, J.C. \& Blanc, P.L. 1987. Variations in mode of formation and temperature of oceanic deep waters over the past 125000 years. Nature, 327:477-482.

Lenters, J.D. \& Cook, K.H. 1999. Summertime precipitation variability over South America: role of the large-scale circulation. Monthly Weather Review, 127:409-431.

Levitus, S. \& Boyer, T. 1994. World Ocean Atlas 1994-Temperature. Washington D.C., U.S. Department of Commerce, National Oceanic and Atmospheric Administration, 117 p. (NOAA Atlas NESDIS 4).

Liu, Z.; Brady, E. \& Lynch-Stieglitz, J. 2003. Global ocean response to orbital forcing in the Holocene. Paleoceanography, 18:1041.

Liu, Z.; Harrison, S.P.; Kutzbach, J. \& Otto-Bliesner, B. 2004. Global monsoons in the mid-Holocene and oceanic feedback. Climate Dynamics, 22:157-182.

Liu, Z.; Otto-Bliesner, B.; Kutzbach, J.; Li, L. \& Shields, C. 2003b. Coupled climate simulation of the evolution of global monsoons in the Holocene. Journal of Climate, 16:2472-2490.

Manabe, S. \& Stouffer, R.J. 1997. Coupled ocean-atmosphere model response to freshwater input: comparison to the Younger Dryas event. Paleoceanography, 12:321-336.

MARGO Project Members, 2009. Constraints on the magnitude and patterns of ocean cooling at the Last Glacial Maximum. Nature Geoscience, 2:127-132.

Martinson, D.G.; Pisias, N.G.; Hays, J.D.; Imbrie, J.; Moore, T.C. \& Shackleton, N.J. 1987. Age dating and the orbital theory of the ice ages: development of a high-resolution 0 to 300,000year chronostratigraphy. Quaternary Research, 27:1-29.

Mayle, F.E.; Beerling, D.J.; Gosling, W.D. \& Bush, M.B. 2004. Responses of Amazonian ecosystems to climatic and atmospheric carbon dioxide changes since the last glacial maximum. Philosophical Transactions of the Royal Society of London B, 359:499-514.

Monnin, E.; Indermühle, A.; Dällenbach, A.; Flückiger, J.; Stauffer, B.; Stocker, T.F.; Raynaud, D. \& Barnola, J.-M. 2001. Atmospheric $\mathrm{CO}_{2}$ concentrations over the Last Glacial Termination. Science, 291:112- 114.

Niebler, H.-S.; Arz, H.W.; Donner, S.; Mulitza, S.; Pätzold, J. \& Wefer, G. 2003. Sea surface temperatures in the equatorial and South Atlantic Ocean during the Last Glacial Maximum (2319ka). Paleoceanography, 18:1069.

Otto-Bliesner, B.L.; Schneider, R.; Brady, E.C.; Kucera, M.; AbeOuchi, A.; Bard, E.; Braconnot, P.; Crucifix, M.; Hewitt, C.; Kageyama, M.; Marti, O.; Paul, A.; Rosell-Melé, A.; Waelbroeck, C.; Weber, S.L.; Weinelt, M. \& Yu, Y. 2009. A comparison of PMIP2 model simulations and the MARGO proxy reconstruction for tropical sea surface temperatures at last glacial maximum. Climate Dynamics, 32:799-815.

Paegle, J.N.; Mechoso, C.R.; Fu, R.; Berbery, E.H.; Chao, W.C.; Chen, T.C.; Cook, K.; Diaz, A.F.; Enfield, D.; Ferreira, R.; Grimm, A.M.; Kousky, V.; Liebmann, B.; Marengo, J.; Mo, K.; Neelin, J.D.; Paegle, J.; Robertson, A.W.; Seth, A.; Vera, C.S. \& Zhou, J. 2002. Progress in Pan American Clivar research: understanding the South American Monsoon. Meteorologica, 27:3-32.
Paegle, J.N. \& Mo, K.C. 2002. Linkages between summer rainfall variability over South America and sea surface temperature anomalies. Journal of Climate, 15:1389-1407.

Paduano, G.M.; Bush, M.B.; Baker, P.A.; Fritz, S.C. \& Seltzer, G.O. 2003. A vegetation and fire history of Lake Titicaca since the Last Glacial Maximum. Palaeogeography, Palaeoclimatology, Palaeocology, 194:259-279.

Pflaumann, U.; Duprat, J.; Pujol, C. \& Labeyrie, L.D. 1996. SIMMAX: a modern analog technique to deduce Atlantic sea surface temperatures from planktonic foraminifer in deep-sea sediments. Paleoceanography, 11:15-36.

Prell, W.L. \& Kutzbach, J.E. 1987. Monsoon variability over the past 150,000 years. Journal of Geophysical Reserach, 92:84118425 .

Roberts, N. 1998. The Holocene. Oxford, Blackwell Publishing, $316 \mathrm{p}$.

Robertson, A.W. \& Mechoso, C.R. 2000. Interannual and interdecadal variability of the South Atlantic Convergence Zone. Monthly Weather Review, 128:2947-2957.

Rühlemann, C.; Mulitza, S.; Müller, P.J.; Wefer, G. \& Zahn, R. 1999. Warming of the tropical Atlantic Ocean and slowdown of thermohaline circulation during the last deglaciation. Nature, 402:511-514.

Rowe. H.D.; Guilderson, T.P.; Dunbar, R.B.; Southon, J.R.; Seltzer, G.O.; Mucciarone, D.A.; Fritz, S.C. \& Baker, P.A. 2003. Late Quaternary lake-level changes constrained by radiocarbon and stable isotope studies on sediment cores from Lake Titicaca, South America. Global and Planetary Change, 38:273-290.

Stute, M.; Forster, M.; Frischkorn, H.; Serejo, A.; Clark, J.F.; Schlosser, P.; Broecker, W.S. \& Bonani, G. 1995. Cooling of tropical Brazil $\left(5^{\circ} \mathrm{C}\right)$ during the Last Glacial Maximum. Science, 269:379-383.

Tapia, P.M.; Fritz, S.; Baker, P.A.; Seltzer, G.O. \& Dunbar, R.B. 2003. A Late Quaternary diatom record of tropical climatic history from Lake Titicaca (Peru and Bolivia). Palaeogeography, Palaeoclimatology, Palaeocology, 194:139-164.

Toledo, F.A.L.; Costa, K.B. \& Pivel, M.A.G. 2007. Salinity changes in the western tropical South Atlantic during the last 30kyr. Global and Planetary Change, 57:383-395.

Tolderlund, D. \& Bé, A.W.H. 1971. Seasonal distribution of planktonic foraminifera in the Western North Atlantic. Micropaleontology, 17:297-329.

Tomczak, M. \& Godfrey, J.S. 2003. Regional oceanography: an introduction. $2^{\text {nd }}$ ed. Dehli, Daya Publishing House, 390 p.

Valdes, P.J. \& Glover, R.W. 1999. Modelling the climate response to orbital forcing. Philosophical Transactions of the Royal Society of London A, 357:1873-1890.

Vera, C.; Higgins, W.; Amador, J.; Ambrizzi, T.; Garreaud, R.; Gochis, D.; Gutzler, D.; Lettenmaier, D.; Marengo, J.; Mechoso, C.R.; Nogués-Paegle, J.; Silva Dias, P.L. \& Zhang, C. 2006. Toward a unified view of the American Monsoon Systems. Journal of Climate, 19:4977-5000.

Vuille, M. \& Werner, M. 2005. Stable isotopes in precipitation recording South American summer monsoon and ENSO variability: observations and model results. Climate Dynamics, 25:401-413.

Wang, L.; Pflaumann, U. \& Sarnthein, M. 1995. Paleo sea surface salinities in low latitude Atlantic: The $\delta^{18} \mathrm{O}$ record of Globigerinoides ruber (white). Paleoceanography, 10:749-761. 
Wirrmann, D.\& Mourguiart, P. 1995. Late Quaternary spatio-temporal limnological variations in the Altiplano of Bolivia and Peru. Quaternary Research, 43:344-354.

Xie, P. \& Arkin, P.A. 1997. Global precipitation: a 17-year monthly analysis based on gauge observations, satellite estimates, and numerical model outputs. Bulletin of the American Meteorological Society, 78:2539-2558.
Zhou, J. \& Lau, K.-M. 1998. Does a monsoon climate exist over South America? Journal of Climate, 11:1020-1040.

Zhou, J. \& Lau, K.-M. 2001. Principal modes of interannual and decadal variability of summer rainfall over South America. International Journal of Climatology, 21:1623-1644.

Received in October, 2009; accepted in April, 2010. 